\title{
Peningkatan kemampuan menulis cerita dengan menggunakan metode picture and picture pada siswa kelas IV SDN 02 Kalirejo
}

\author{
Fiqih Athaini \\ SD Negeri 02 Kalirejo Kec.Talun Kab.Pekalongan
}

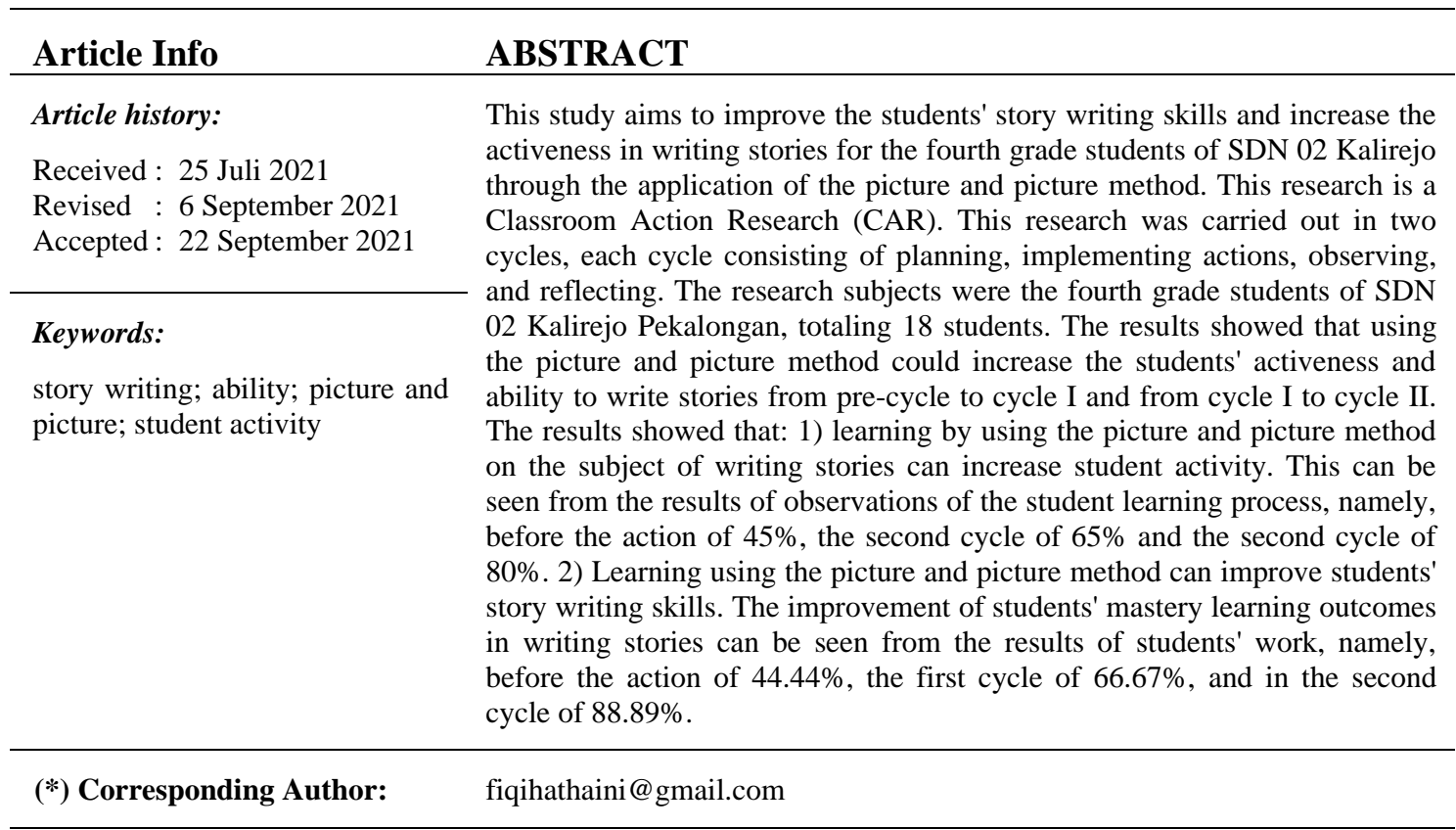

How to Cite: Athaini, F. (2021). Peningkatan kemampuan menulis cerita dengan menggunakan metode picture and picture pada siswa kelas IV SDN 02 Kalirejo. Action Research Journal, 1(1): 47-52.

\section{PENDAHULUAN}

Menulis merupakan aktivitas yang penting pada materi pengajaran Bahasa Indonesia di Sekolah Dasar. Menulis adalah satu kompetensi bahasa yang ada dalam setiap jenjang pendidikan, mulai tingkat prasekolah hingga perguruan tinggi. Melalui menulis, maka keterampilan berbahasa dapat dikuasai siswa dengan baik. Mulyati (2008) menjelaskan bahwa menulis merupakan proses berfikir untuk menuangkan pemikiran itu dalam bentuk wacana (karangan). Ini menunjukkan bahwa mengarang merupakan keseluruhan rangkaian kegiatan seseorang untuk mengungkapkan gagasan dan menyampaikannya melalui bahasa tulis kepada pembaca untuk dipahami secara tepat seperti yang dimaksudkan oleh penulis atau pengarang. Karangan memiliki klasifikasi dan jenis yang beragam. Wacana narasi merupakan salah satu jenis wacana yang berisi cerita (Sulfemi \& Minati, 2018; Handayani et al., 2017). Hal ini berarti menulis cerita adalah salah satu jenis karangan.

Menulis cerita merupakan kompetensi menulis yang harus dikuasai siswa sejak jenjang sekolah dasar. Melalui kegiatan menulis cerita, maka seorang siswa dapat mencurahkan perasaan, ide, dan gagasannya kepada orang lain. Kemampuan menulis cerita tidak dapat langsung dikuasai siswa, melainkan harus melalui latihan dan praktik yang teratur sehingga siswa mudah berekspresi dalam kegiatan menulis (Mundziroh, Sumarwati, \& Saddhono, 2013). Oleh karena itu, kemampuan menulis harus dilatihkan ke siswa sejak siswa berada di sekolah dasar. Dengan demikian, maka kemampuan siswa untuk mengungkapkan gagasan melalui bentuk tulisan akan semakin berkembang. 
Namun demikian, fakta dilapangan dan berdasarkan pengamatan peneliti sebagai guru kelas menunjukkan kemampuan menulis cerita siswa kelas kelas IV SDN Kalirejo Pekalongan masih rendah. Ini terlihat dalam pembelajaran menulis cerita masih banyak siswa yang mendapat nilai di bawah KKM. Diperoleh hasil bahwa 10 dari 18 siswa masih memperoleh nilai di bawah KKM, sedangkan 8 siswa mendapatkan nilai di atas KKM (kentuntasan belajar hanya mencapai 44,44\%). Hal ini dikarenakan siswa tidak runtut dalam menulis cerita, ide utamanya masih belum terlihat dan urutan tidak logis. Kenyataan ini menunjukkan bahwa guru harus mencari inovasi untuk dapat membimbing siswa menulis cerita. Selain itu, guru juga harus membantu siswa yang mengalami kesulitan dalam mengembangkan gagasan untuk menulis cerita.

Salah satu pembelajaran inovatif yang dapat diterapkan adalah melalui pembelajaran picture and picture. Pembelajaran picture and picture adalah model pembelajaran yang kooperatif atau mengutamakan adanya kelompok dengan media gambar yang dipasangkan atau diurutkan menjadi urutan logis (Kurniasih \& Sani, 2016). Model pembelajaran picture and picture sangat cocok diterapkan untuk muatan materi Bahasa Indonesia karena memuat pasangan gambar yang dapat diurutkan menjadi urutan logis. Melalui gambar-gambar tersebut, membuat muatan materi Bahasa Indonesia menjadi lebih menarik dan bermakna karena siswa diberikan kesempatan untuk membangun pengetahuannya sendiri melalui berbagai kegiatan seperti menyusun dan mengurutkan gambar kemudian dibuat menjadi cerita. Pembelajaran picture and picture mengandalkan gambar sebagai media dalam proses pembelajaran. Gambargambar ini menjadi faktor utama dalam proses pembelajaran. Sehingga sebelum proses pembelajaran guru sudah menyiapkan gambar yang akan ditampilkan baik dalam bentuk kartu atau dalam bentuk carta (Sukiman, 2012; Kurniati, 2013; Riyono \& Retnoningsih, 2015).

Berdasarkan uraian di atas, rumusan masalah dalam penelitian ini adalah bagaimana peningkatan kemampuan menulis cerita siswa dan keaktifan dalam menulis cerita siswa kelas IV SDN 02 Kalirejo melalui penerapan metode picture and picture.

\section{METODE}

Jenis penelitian yang digunakan pada penelitian ini adalah penelitian tindakan kelas yang merupakan suatu pencermatan terhadap kegiatan belajar berupa sebuah tindakan yang sengaja dimunculkan dan terjadi dalam sebuah kelas. PTK merupakan suatu penelitian yang akar permasalahannya muncul di kelas dan dirasakan langsung oleh guru yang bersangkutan (Arikunto, 2010). Prosedur penelitian ini mencangkup tahapan-tahapan sebagai berikut: 1) perencanaan, 2) penerapan tindakan, 3) mengobservasi dan mengevaluasi proses dan hasil tindakan, dan 4) melakukan refleksi. Dan seterusnya sampai perbaikan atau peningkatan yang diharapkan tercapai (kriteria keberhasilan)

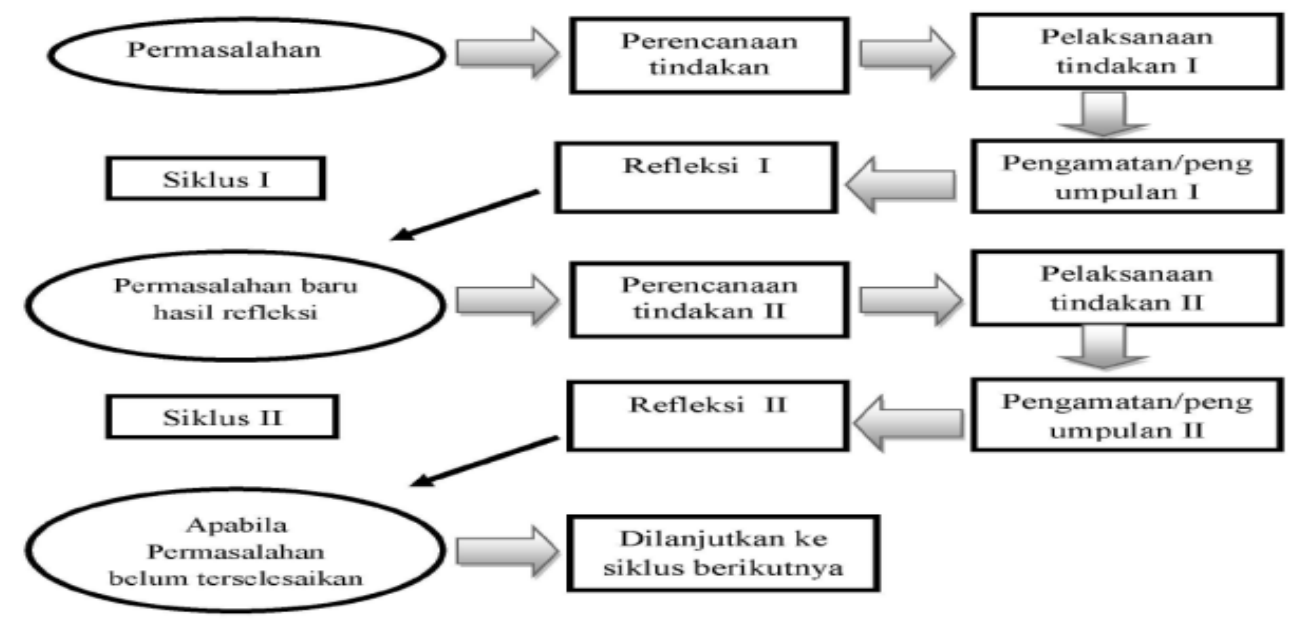

Gambar 1. Alur Penelitian Tindakan Kelas 
Subjek dalam penelitian ini adalah siswa kelas IV SDN Kalirejo Kabupaten Pekalongan yang berjumlah 18 siswa. Metode pengumpulan data yang digunakan dalam penelitian ini yaitu tes, dokumentasi dan observasi. Data tentang pelaksanaan penelitian digunakan untuk mengetahui keaktifan siswa dalam mengikuti kegiatan pembelajaran diperoleh dari data hasil observasi. Tes digunakan adalah ulangan dengan bentuk soal uraian yang diberikan pada akhir siklus. Sedangkan dokumentasi digunakan untuk memperoleh hasil kerja produk hasil menulis cerita siswa.

Teknik analisis data yang digunakan adalah deskriptif baik secara kualitatif maupun kuantitatif. Untuk tes hasil belajar siswa, dihitung jumlah skor dari masing-masing siswa dengan rumus rata-rata sebagai berikut.

Mean $=\frac{\sum x}{N}$

Keterangan

Mean = nilai rata-rata siswa

$\sum x \quad=$ jumlah nilai seluruh siswa

$N \quad=$ jumlah siswa

Untuk menghitung persentase ketuntasan klasikal kelas dapat ditentukan menggunakan rumus sebagai berikut.

Persentase $=\frac{\text { jumlah siswa yang tuntas atau belum tuntas }}{\text { jumlah seluruh siswa }}$

Kriteria keberhasilan yang ditetapkan dalam penelitian ini adalah ketuntasan belajar siswa yang dilihat dari kemampuan menulis cerita jika proporsi nilai siswa lebih dari KKM yang telah ditetapkan dan untuk ketuntasan belajar klasikal jika minimal 85\% siswa mendapat nilai diatas KKM yang telah ditetapkan yaitu 70, dan keaktifan siswa dalam mengikuti proses pembelajaran matematika meningkat dengan persentase minimal $75 \%$ dari skor maksimal.

\section{HASIL DAN PEMBAHASAN}

Sebelum pelaksanaan penelitian, observasi dilakukan saat pembelajaran menulis cerita yang dilaksanakan di kelas siswa kelas IV SDN Kalirejo Kabupaten Pekalongan. Dari kegiatan ini diketahui kondisi nyata yang terjadi pada pembelajaran menulis cerita siswa kelas IV SDN Kalirejo Kabupaten Pekalongan. Dari observasi awal ini juga diketahui bahwa terdapat masalah dalam pembelajaran menulis cerita. Kemudian, peneliti menyusun rencana pelaksanaan pembelajaran (RPP) untuk memperbaiki pembelajaran menulis cerita dengan metode picture and picture. Kelemahan-kelemahan pada siklus I seperti guru kurang mengelola kelas dengan baik karena banyak kegiatan yang seharusnya dilakukan sesuai dengan RPP tetapi belum terlaksana, dan siswa kurang aktif dalam mengikuti pembelajaran menulis cerita diperbaiki dalam siklus berikutnya.

Hasil penelitian dari siklus I dan siklus II menunjukkan bahwa pembelajaran dengan picture and picture dapat meningkatkan kemampuan siswa dalam menulis cerita. Kemampuan siswa dalam pembelajaran menulis cerita dapat dilihat dari nilai yang diperoleh siswa dalam menghasilkan sebuah cerita. Nilai tersebut terus mengalami peningkatan dari siklus ke siklus. Cerita yang dihasilkan siswa mengalami peningkatan dalam beberapa aspek baik dari isi, organisasi, kosa kata, penggunaan bahasa dan mekanik. Hal ini ditunjukkan dari hasil analisis evaluasi pada siklus I dengan rata-rata kemampuan menulis siswa 67 dengan ketuntasan klasikal 66,67\%, sedangkan hasil analisis evaluasi siklus II diperoleh nilai rata-rata siswa 86 dengan ketuntasan klasikal 88,89\% sehingga indikator keberhasilan tercapai. Hal ini ditunjukan pada Tabel 1 berikut. 
Tabel 1. Persentase Kemampuan Menulis Cerita

\begin{tabular}{lccc}
\hline & Pra Siklus & Siklus I & Siklus II \\
\hline Jumlah Siswa Tuntas & 8 & 12 & 16 \\
Persentase Siswa Tuntas & $44,44 \%$ & $66,67 \%$ & $88,89 \%$ \\
Jumlah Siswa Tidak Tuntas & 10 & 6 & 2 \\
Persentase Siswa Tidak Tuntas & $55,56 \%$ & $33,33 \%$ & $11,11 \%$ \\
Rata-rata & 50 & 67 & 86 \\
\hline
\end{tabular}

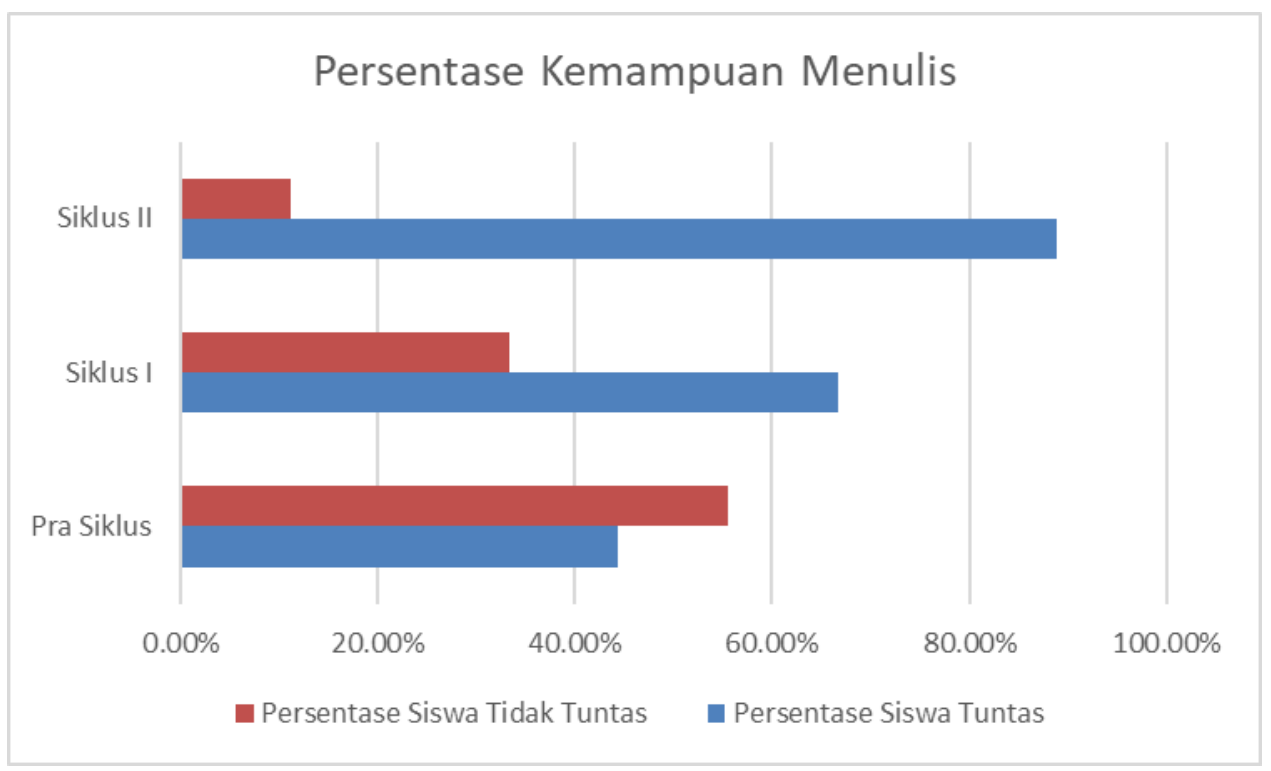

Gambar 2. Peningkatan Kemampuan Menulis

Pada tabel di atas terlihat adanya peningkatan ketuntasan belajar klasikal dari siklus I sebesar 66,67\% dengan jumlah siswa yang tuntas sebanyak 12 siswa menjadi 88,89\% dengan jumlah siswa yang tuntas 16 siswa. Rata - rata kelas juga mengalami peningkatan dari 67 pada siklus I meningkat menjadi 86 pada siklus II. Peningkatan hasil belajar siswa ini dikarenakan adanya variasi dalam proses pembelajaran berupa penerapan pembelajaran picture and picture, supaya guru lebih memberikan kesempatan pada siswa agar lebih aktif dan dapat menemukan ide dalam menyusun cerita (Sulfemi, W. B., \& Minati, 2018; Kurniati, 2013).

Dari hasil analisis peneliti dapat diketahui bahwa keaktifan siswa pada siklus I mencapai $65 \%$, meningkat jauh lebih baik dari sebelumnya (survei awal) yang kurang dari 45\%. Pada siklus II, keaktifan siswa meningkat menjadi $80 \%$ artinya jumlah siswa yang aktif bertambah 3 siswa. Siswa yang aktif dalam siklus II ini adalah 15 siswa dari 18 siswa. Dari hasil analisis di atas, maka dapat dikatakan bahwa tindakan yang dilakukan guru untuk meningkatkan keaktifan siswa berhasil. Hal ini membuktikan bahwa metode picture and picture memiliki peran dalam meningkatkan keaktifan siswa dalam proses belajar mengajar. Berikut disajikan Gambar 3 yang menunjukkan peningkatan persentase keaktifan pembelajaran menulis cerita dengan metode picture and picture pada siswa kelas IV SDN Kalirejo Kabupaten Pekalongan. 


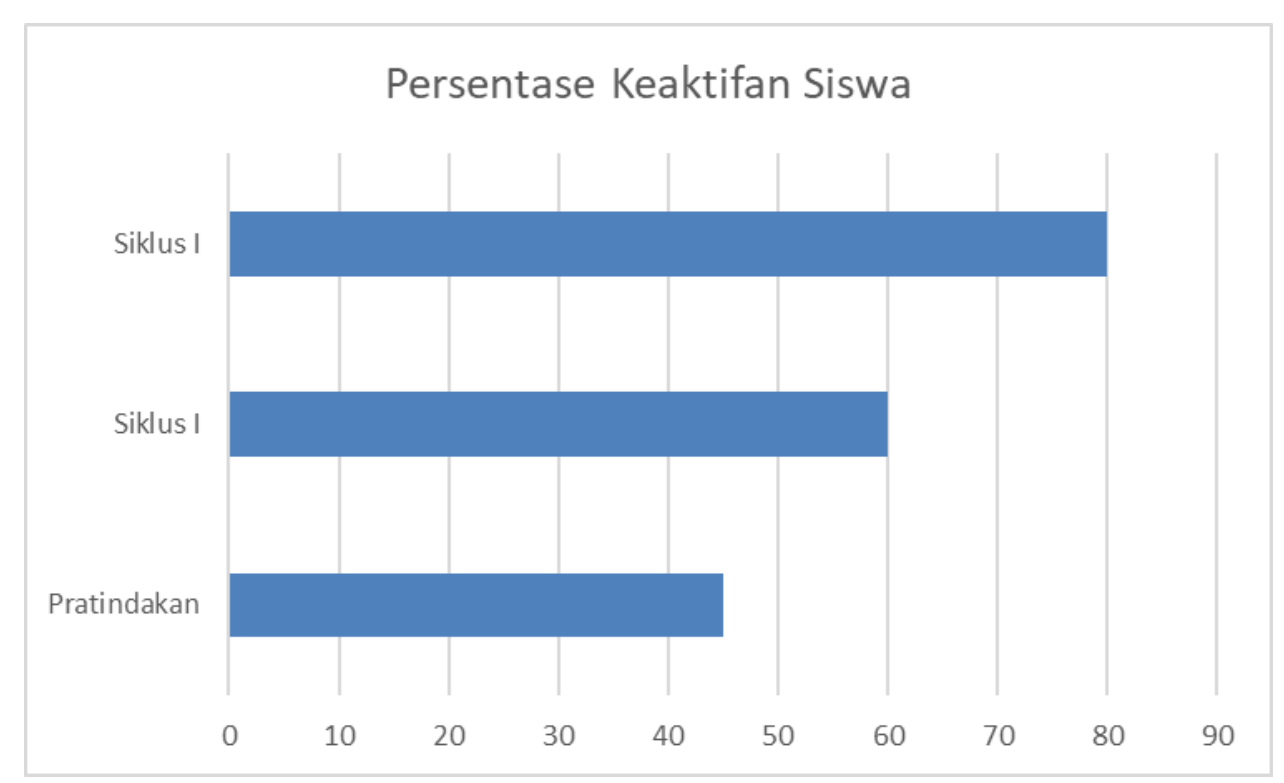

Gambar 3 Peningkatan Keaktifan Siswa

Meningkatnya keaktifan siswa dikarenakan dilibatkannya siswa secara langsung dalam penggunaan, pemanfaatan gambar-gambar yang berseri untuk dapat disusun menjadi cerita menyebabkan siswa tertarik dan juga dapat berinteraksi dengan guru dan siswa lainnya dalam pembelajaran sehingga aktifitas siswa dalam perhatian, bertanya, berpendapat, menjawab, dan berdiskusi meningkat. Picture and picture menjadi salah satu alternatif pemecahan masalah diharapkan dapat meningkatkan kemampuan siswa dalam menulis. Model pembelajaran kooperatif tipe picture and picture merupakan salah satu model merupakan suatu metode belajar yang menggunakan gambar yang dipasangkan atau diurutkan menjadi urutan logis (Hamdani, 2011). Keuntungan dari model pembelajaran ini adalah membantu meningkatkan daya nalar siswa dengan menganalisa gambar secara berurut serta membantu peserta didik dalam mengembangkan ide, kreativitas dalam menulis.

Hasil penelitian ini diperkuat oleh hasil penelitian yang dilakukan oleh Kurniati (2013) dengan hasil kesimpulan penelitian yakni model pembelajaran picture and picture memberikan pengaruh terhadap hasil belajar IPA siswa kelas V SD semester genap di Gugus I Kecamatan Buleleng. Penelitian lain yang dilakukan oleh Sulfemi \& Minati (2018) dan Mundziroh, Sumarwati, \& Saddhono (2013) yang menyimpulkan bahwa bahwa terdapat pengaruh model pembelajaran picture and picture terhadap kemampuan menulis siswa serta terjadi peningkatan yang signifikan dari keaktifan siswa selama proses pembelajaran.

\section{PEMBaHASAN}

Dari hasil penelitian siklus I dan siklus II menunjukkan bahwa pembelajaran dengan picture and picture dapat meningkatkan kemampuan siswa dalam menulis cerita. Kemampuan siswa dalam pembelajaran menulis cerita dapat dilihat dari nilai yang diperoleh siswa dalam menghasilkan sebuah cerita. Nilai tersebut terus mengalami peningkatan dari siklus ke siklus. Cerita yang dihasilkan siswa mengalami peningkatan dalam beberapa aspek baik dari isi, organisasi, kosa kata, penggunaan bahasa dan mekanik. Hal ini ditunjukkan dari hasil analisis evaluasi pada siklus I dengan rata-rata kemampuan menulis siswa 67 dengan ketuntasan klasikal 66,67\%, sedangkan hasil analisis evaluasi siklus II diperoleh nilai rata-rata siswa 86 dengan ketuntasan klasikal 88,89\% sehingga indikator keberhasilan tercapai

Dari hasil analisis peneliti dapat diketahui bahwa keaktifan siswa pada siklus I mencapai $65 \%$, meningkat jauh lebih baik dari sebelumnya (survei awal) yang kurang dari 45\%. Pada siklus II, keaktifan siswa meningkat menjadi $80 \%$ artinya jumlah siswa yang aktif bertambah 3 
siswa. Siswa yang aktif dalam siklus II ini adalah 15 siswa dari 18 siswa. Dari hasil analisis di atas, maka dapat dikatakan bahwa tindakan yang dilakukan guru untuk meningkatkan keaktifan siswa berhasil. Hal ini membuktikan bahwa metode picture and picture memiliki peran dalam meningkatkan keaktifan siswa dalam proses belajar mengajar

\section{PENUTUP}

Berdasarkan hasil penelitian tindakan kelas yang dilaksanakan dalam dua siklus, maka dapat ditarik simpulan bahwa pembelajaran dengan menggunakan metode picture and picture dapat meningkatkan kemampuan siswa dalam menulis cerita dan keaktifan siswa dalam pembelajaran menulis cerita siswa kelas IV SDN Kalirejo Kabupaten Pekalongan. Saran dalam penelitian ini adalah guru hendaknya lebih kreatif dan inovatif dalam pembelajaran sehingga semakin menyenangkan.

\section{DAFTAR PUSTAKA}

Arikunto, S. (2010). Metode penelitian. Jakarta: Rineka Cipta.

Handayani, N. M. D., Ganing, N. N., \& Suniasih, N. W. (2017). Model Pembelajaran Picture and Picture Berbantuan Media Audio-Visual Terhadap Kompetensi Pengetahuan IPA. Journal of Education Technology, 1(3), 176-182.

Kurniasih, Imas\& Berlin Sani. 2015. Ragam Pengembangan Model Pembelajaran untuk Meningkatkan Profesionalitas Guru. Jakarta: Kata Pena

Kurniati, N.M. (2013). Pengaruh Model Pembelajaran Picture and Picture Terhadap Hasil Belajar IPA Siswa Kelas IV SD Semester Genap di Gugus I Kecamatan Buleleng. Skripsi ( tidak diterbitkan ). Jurusan Pendidikan Guru Sekolah Dasar.

Mulyati, Y. (2008). Keterampilan Berbahasa Indonesia SD. Jakarta: Universitas Terbuka.

Mundziroh, S., Sumarwati, S., \& Saddhono, K. (2013). Peningkatan kemampuan menulis cerita dengan menggunakan metode picture and picture pada siswa sekolah dasar. Basastra, 1(2), 318-327.

Riyono, B., \& Retnoningsih, A. (2015). Efektivitas model pembelajaran picture and picture dengan strategi inkuiri terhadap motivasi dan hasil belajar siswa. Journal of Biology Education, 4(2).

Sukiman. (2012). Pengembangan Media Pembelajaran. Yogyakarta: Pedagogia

Sulfemi, W. B., \& Minati, H. (2018). Meningkatkan Hasil Belajar Peserta Didik Kelas 3 SD Menggunakan Model Picture And Picture dan Media Gambar Seri. JPSD (Jurnal Pendidikan Sekolah Dasar), 4(2), 228-242. 